\title{
President John F. Kennedy's Declaration of Interdependence: A Study in his Presidential Rhetoric
}

By

Erik A. Hansen

Associate Professor, University of Aarhus

This paper will focus on John F. Kennedy's Fourth of July speech 1962. I will try to indicate that the speech was more than ordinarily well-prepared, and that it was meant to stand as a central expression of the Administration's goals and modes of operation.

That the speech has attracted comparatively little attention in Kennedy historiography may have to do with the fact that it was central in Kennedy's Grand Design complex, and that Arthur Schlesinger, Jr., one of the two great inside chroniclers of the Kennedy Administration ${ }^{1}$ found it right to speak about the Grand Design a little apologetically, in a chapter of his A Thousand Days (New York, 1965) entitled "The Not So Grand Design". More specifically the design was linked with the energy invested in the passing of the Trade Expansion Act 1962. Schlesinger says that "Some of us felt ... (it) was a misdirection of the Administration's limited resources".1 Seymour E. Harris, in his Economics of the Kennedy Years (London, 1954) speaks rather briefly about the trade problems, but he does say about the passage of the TEA that it was Kennedy's "greatest domestic triumph".2

In more recent literature Bruce Miroff (1976) writes excellently about Kennedy's conception of and dramatic use of the Presidency. ${ }^{3}$ Kennedy was expert in the confrontational crisis presidency, crises largely self-provoked and under control, a tradition picked up from Truman and then perfected. ${ }^{4}$ This view may clearly be linked up with Henry Fairly's ironical book The Kennedy Promise (New York, 1972). It might indeed also be thought of as an 
academically urbane counterpart to Victor Lasky's notorious JFK: The Man and the Myth (New York, 1963), on the bestseller list during the spring and summer of 1963 until it was taken out of circulation on November 23. Bruce Miroff and Henry Fairly do not concern themselves with K's TEA complex, but their insistence on K's use of "dramatisation" gives a useful hint, since it leads to awareness of symbolic politics ${ }^{5}$ as perhaps more than generally present in K's administration and, indeed, close to its substance.

The original inspiration behind the following pages dates back to Joseph Kraft's The Grand Design (New York, 1962). This little "synthesis" was felt then, and can still be felt, as something of a primary source, since it was written with "the kind cooperation of officials in the Kennedy Administration, and to a certain extent reflects their views". ${ }^{6}$ More recently Jim H. Heath bas described very soberly John F. Kennedy and the Business Community (Chicago, 1969). In his brief chapter on TEA he is very factual, and he does not play it up as a pattern in the carpet, but what he says about Kennedy's fundamental allegiance to the American business creed is useful.'

\section{IIa. Background of the Speech}

The Democratic Platform 1960 and Kennedy's campaign speeches up to the party convention as collected in The Strategy of Peace (New York, 1960) were calls for expansion of the economy, closer coordination of domestic and foreign policy, and special attention to "The Atlantic Community". The European Common Market, an outgrowth of the Marshall Plan, represented a challenge to the USA. With its external tariff wall it might divert trade in regard to Latin America and Japan ${ }^{\mathrm{a}}$ (which would raise many problems for the USA, including security problems). With its high interest rate it would mean an inflow of American capital and the loss of jobs to American workers. The balance of payments had been negative since 1957, in spite of America's trade surplus. The negative balance stemmed from military outlay, and from American firms wanting to invest inside the EEC. Thus the dollar was threatened, the Pax Americana was disturbed. ${ }^{9}$

With his narrow victory in November 1960 Kennedy opted for a high degree of bipartisanship in his Administration. The three eldest departments in the cabinet were given to Republicans with good standing in the Eastern Establishment. A special signal was 
given with the appointment of Douglas Dillon as Secretary of the Treasury. He had been Assistant Secretary of State for Economic Affairs under the Atlanticist Christian Herter, Foster Dulles's successor at the State Department. And an equally important signal was that George Ball, Democrat with links to Dean Acheson and Jean Monnet, was made Under Secretary of State for Economic Affairs.

The Administration's first important step was organization of $\mathrm{OECD}^{10}$ (with USA and Japan as members); the next: preparation of new trade legislation, since the old Reciprocal Trade Agreements Act (dating back to Gordell Hull's initiative in 1934) was up for regular renewal in 1962; the third: through executive and minor legislative actions acceleration of the recovery out of the 1960 recession (the third during the 50's). ${ }^{11}$

With 60 per cent of the population being affluent it was obviously difficult politically to get the country moving again, to "make it come alive", as he had said with a quotation from Walter Lippmann..$^{12}$ But the employment situation called for action. The post-war population explosion was hitting the labor market (as well as altering the population profile: more young and old people with ensuing problems in education and social welfare). Women were entering the labor force. Agriculture had since the War been undergoing rapid industrialization. And automation was threatening to become an uncontrollable Frankenstein, America's "Enemy No. One", as George Meany proclaimed. With an unemployment at 6-7 per cent, social unrest might be foreseen among teenagers and especially among Blacks. The Cuban crisis in the spring of 1961 and then the Berlin crisis in the summer allowed a boosting of defense expenses (soon with 25 per cent), and, with some difficulty, without increased taxation. To hold down inflationary pressures a "guide line principle" (adopted from De Gaulle's France) was introduced, as described in his second Economic Report.13 Under OECD agreement the 60 's were to be a growth decade ( 50 per cent), with the annual real productivity growth set at 4 per cent, and the increase in wages and prices at 3.5 per cent. With such a guideline the individual customer could police the prices. Another way of ensuring real productivity gains was adoption of intensive antitrust politics through the Attorney General's Anti-Trust Division (the Sherman Act), not least against the new conglomerates. The trend towards administered prices in the corporate sector was thus challenged. Cost-efficiency was similarly to be emphasized in 
Robert McNamara's defense sector (where open price-bidding was usually impossible). And war was soon organized against organized crime (from the Justice Department). The Administration thus relied heavily on energetic administration of existent laws, as was also the case in the area of civil rights. This strategy seemed prudent in the face of a conservative, rurally controlled, Congress.

The guideline policy led to a dramatic collision in May 1962 with Roger Blough, chairman of USS (United States Steel). Mr. Blough suddenly broke the "rules" of the game when he announced a price-hike in steel. Through K's appeal to public opinion, and through threatened re-allocation of defense-contracts to firms willing to ignore USS's price-leadership, Roger Blough was coerced to rescind the price increase. USA had proved stronger than USS. American free enterprise stood revealed as a presidentially policed economy, and this new development had come about through "Defense". In his Yale Address K clothed his speech in "gay magic" to use James Reston's phrase, ${ }^{14}$ he spoke in a friendly, almost jocose, way about his recent encounter with Mr. Blough, but he let it also be firmly understood that the Presidency was "not totally without resources" in such situations. ${ }^{15}$ Later that summer he voiced his American belief in "the free market as a decentralized regulator of our economic system ... (it) keeps economic power widely dispersed ... (it) is a vital underpinning of our democratic system" ${ }^{16}$ But the point is, however, that such Wilsonian liberalism would necessitate strong government to keep the milieu competitive and non-arbitrary. ${ }^{17}$

\section{IIb. TEA Launched}

American liberalism has since Woodrow Wilson (the Southerner) relied on, in addition to anti-trust, a lowering of the tariff so as to obtain freer trade. With America coming of age as an industrial giant around the turn of the century, it was increasingly in need of "open doors", and not least after it became a creditor nation shortly before WW I. Hence Wilson's Underwood Tariff in 1914 and his later fight for the League of Nations to ensure universal access for American ships, goods, and capital. ${ }^{\mathbf{1 8}}$ With the New Deal, Roosevelt had relied primarily on the national solution, but Underwood's disciple Cordell Hull (also a Southerner) had been allowed as Secretary of State to work for reciprocal trade agreements since 1934 as a side show. ${ }^{19}$ Dean Acheson, the conservative 
Baltimore Democrat who had been critical of the First New Deal's "nationalism" came back into the Roosevelt team during the War years and as the war was coming to an end, he was warning against a resumption of the New Deal, since it would mean destruction of the American system of government. A global deal was necessary, with external expansion.

The EEC challenge provided $\mathrm{K}$ with an opportunity to pursue the rhetoric of competition and free trade liberalism. He advocated a reshaping and expansion of the Reciprocal Trade Agreements Act up for renewal in 1962. Up-dated trade legislation had indeed been called for by Eisenhower in his last Economic Report 1961 (presumably at the instigation of Christian Herter and Douglas Dillon). So while carefully nursing' the economy into greater efficiency with the help of the increased defense budget he saw a Trade Expansion Bill as the centerpiece for 1962. ${ }^{20}$ The Democratic Platform 1960 had said:

World trade is more than ever essential to world peace. In the tradition of Cordell Hull we shall expand world trade in every responsible way. ${ }^{21}$

Our Government should press for reduction of foreign barriers to the sale of the products of American industry and agriculture . . .22

With regard to the Atlantic Community a "broader partnership" was proposed. The Democrats promised to

restore the former high level of cooperation within the Atlantic Community envisaged from the beginning by the NATO treaty in political and economic spheres as well as military affairs. ${ }^{23}$

They would negotiate with "the nations of the Common Market" to encourage freer trade, and would encourage "adjustment with the so-called 'Outer Seven' so as to enlarge further the area of freer trade." 24

Should USA try to join the Common Market (as proposed by some, e.g. William Clayton and Christian Herter)? Or should it join EFTA? Or should it work for a "partnership" with England and other EFTA countries included in the EEC. ${ }^{25}$ This third strategy hinted at in the platform pointed to a reconstitution of the Atlantic Community, at least in regard to trade, under the auspices of GATT. When Konrad Adenauer visited Washington on November 22, 1961, he and Kennedy spoke in their communiqué about strong support for EEC and: 
they agreed particularly on the importance and significance of proposals now being considered for a European Political Union pursuant to the Bonn Declaration of July 1961.26

The Administration's assumption was that MacMillan's decision in the summer of 1961 to apply for membership in EEC would go through. But the problems were many. Would England want to move into a Political Union (Adenauer's Federalist dream)? Was de Gaulle not a Confederationist? And would he make concessions to England in regard to agriculture and the Commonwealth problems ? ${ }^{27}$ But in disregard of these intricacies the Administration moved ahead, thereby coercing England as well as France. George Ball and McGeorge Bundy made speeches during November about "partnership between the United States, on the one hand and a great European power on the other". ${ }^{28}$ And K himself tried out next year's "centerpiece" in November at a NAM meeting in New York and an ALF-GIO meeting in Florida. ${ }^{29}$ The educational campaign was under way and the opinion mafia was set to work. In his second Message on the State of the Union (Jan. 11, 1961) he said:

... the Atlantic Community is no longer concerned with purely military aims. ${ }^{30}$ ... the greatest challenge of all (trade problems) is posed by the European Common Market. Assuming the accession of the United Kingdom, there will arise across the Atlantic a trading partner behind a single external tariff similar to ours with an economy which nearly equals our own. Will we in this country adapt our thinking to these new prospects and patterns ... or will we wait until events have passed us by?

This is the year to decide. ... We need a new law - a wholly new approach, a bold new instrument of American trade policy. Our decision could well affect the unity of the West, the course of the Cold War, and the economic growth for a generation to come....

... The Common Market is moving ahead at an economic growth rate twice ours. The Communist economic offensive is under way. The opportunity is ours. ... The initiative is up to us. ... . ${ }^{31}$

In the Message accompanying his first Economic Report (Jan. 22, 1962) he spoke about the need for increasing the US trade surplus, and for reducing the "artificial incentive to US firms to invest abroad. The European Common Market has attracted American

On Jan. 25 he sent the new bill to Congress with a message in which he said that America's fair share in the rapidly growing European market would mean jobs; the "healthy competition from 
abroad" would keep down inflation and supplement anti-trust and other efforts to assure competition; and through the "most favored nation" principle it would be a help to Latin America, Japan, and other countries. The Act will "mark the beginning of a new chapter in the alliance of free nations"' ${ }^{33}$

The bill comprised the following major points: ${ }^{34}$

a) Tariff would be eliminated in regard to groups of goods where the two partners represented $80 \%$ of the world trade.

b) $50 \%$ tariff reduction, reciprocally.

c) Reduction or elimination of tariffs against agricultural products from underdeveloped countries.

d) New procedures for negotiation: across the board rather than item by item. A special trade representative would be appointed under the Executive and with the rank of ambassador (Christian Herter was appointed); ${ }^{35}$ he would be heading a bi-partisan commission. The negotiating authority would be given for 5 years, whereas previously 4 years had been maximum.

e) An Adjustment Assistance Program at home to help workers and industries that might be hurt by the new tariffs and therefore be in need of retraining or re-tooling. The program was meant to supplement the traditional "escape clause" which had in the 50's come to erode the American free trade position at GATT, e.g. in the "Douglas Dillon Round" since 1958 (expiring in 1962)..$^{36}$

The bill was passed by the House on June 28 with 298 votes for, 125 votes against; in the Senate on September 19 with 78for, and 8 against. ${ }^{37}$ It was signed by $\mathrm{K}$ on October 14 , and at the ceremony he said that it marked "a dynamic new era of growth" and a "weapon against the Communist world"' ${ }^{38}$

The surprisingly big majorities in Congress may of course stem from the President's well-orchestrated and dramatized campaign. But there may also be other reasons. A big, multi-disciplinary study conducted at the Massachusetts Institute of Technology had its data available in 1961 and was published in 1963: Raymond Bauer et al., American Business and Public Policy: The Politics of Foreign Trade (New York, 1963). The study found that whereas formerly Democrats had been for and Republicans in general against free trade, there had since WWII been new developments in attitudes: Southern Democrats were under pressure for protection in textiles and for non-importation in oil; Eastern Republicans, conversely, were increasinglyfor free trade. Another finding was that big firms (with diverse interests) would in general give the issue a low priority. ${ }^{39}$ Robert Dahl has emphasized, like V. O. Key ${ }^{\mathbf{4 0}}$ before him, that American business is not monolithic, and that educated 
opinion is generally for free trade. Protectionist sentiment, says Dahl, is found in single-issue pressure-groups connected with such tariff-conscious industries as wool, bicycles, glass, chemicals, and then in such labor unions as the United Mine Worker. ${ }^{41}$ Under a conciliatory President, like Eisenhower, such pressure-groups would be effective, under a more aggressive president, like Kennedy, their disproportionate influence would be curtailed. Who would, then, in general be for the TEA? The Southerners (with Wilbur Mills as Chairman of "Ways and Means") would in obedience to their Southern "liberal" tradition be for. ${ }^{42}$ So would the leadership of National Association of Manufacturers and, though less certainly because speaking for smaller business, the Chamber of Commerce. And the Labor Unions would be for (at least the leadership), since the TEA would to some extent diminish the multinational corporations' export of jobs to the Common Market.

Finally the growing number of "intellectuals" would be for. The idea of unity in multiplicity (e pluribus unum) would naturally appeal to the intellectuals' professional simple-mindedness. The Atlantic idea based on the age-old wish for a re-uniting of the Old World and the New appealed to American Anglo-Saxonism with a fondness for the Latin Quarter in Paris and with an essentially ADA conscience. 43 As representative of the new growing suburbia they would of course also be for "lower prices", not least on food. A rejuvenated ADA sentiment in the guise of Atlanticism would, however, not only be natural to "intellectuals" but also to New Immigrant workers who had "made it" as Americans and whose Catholic or Jewish creed would overlap with the universalism inherent in the American creed of liberalism itself. ${ }^{44}$

More specifically the concept of an "Atlantic System" has a long and fascinating history in the USA. Already Henry Adams advocated it in 1905 in a letter to John Hay:

We want our Atlantic system - which extends from the Rocky Mountains, on the West, to the Elbe on the East. ${ }^{45}$

Andrew Carnegie pleaded for a reunion of Great Britain and the United States in a new nation called "the Reunited States". ${ }^{46}$ And Alfred Mahan supported the idea.47 The imperial school in American history can obviously be thought of as lending support to the same kind of thinking, as can the many transatlantic marriages around the turn of the century, Henry James's exploration of "the international theme" (resurrected by Fulbright scholars after 
WW 11), and Ezra Pound's landing at Gibraltar in 1908 (as if to put in one more claim about the poets as the antennae of the tribe). ${ }^{47}$ In 1917 Walter Lippmann wrote a famous editorial in The New Republic about the Atlantic system based on "Athenian" sea powers (with no "standing army") committed to commerce and Lockean democracy versus the Continental "Spartan" powers (then Prussia, now Russia) committed to land-forces, hierarchy, and Hobbesian absolutism. ${ }^{48}$ The article summed up a great deal of the messianic impulse behind Wilson's conception of a new

(American) world order, as now later after WWII also behind J.F.K's vision. Poetry, geo-politics, strategy, and economics went well together, as J.F.K. spoke about the TEA as beneficial to the "growth industries", among others those concerned with food production, food machinery, electronics, helicopters, airplanes, chemicals, and "know how". 49

Harold Van B. Cleveland has noted very soberly that the US Congress converted to free trade because they feared European power and thought that within a partnership (multilateral and liberal) "American interest would not come off second best". EEC should be made "outward-looking", 50 and this meant, indeed, that the good fight against Communism was a fight for universalist "open doors" under American-Atlanticist auspices. Some might even think of England's inclusion as somehow including also the Commonwealth, in other words Winston Churchill's English Speaking Peoples ${ }^{51}$.

George Ball was undoubtedly the leading spokesman for the new Atlantic partnership, ${ }^{52}$ and it was appropriate that his "teacher" Jean Monnet would announce on June 26, 1962 :

The economic and political unity of Europe, including England, and the establishment of European-American relations as between equal partners will alone permit the consolidation of the West, and thus, the creation of the conditions for peace between East and West. ${ }^{53}$

This formulation can of course be reconciled with Raymond Aron's reasoning that "in the last resort, dialogue with the Soviet Union meant more to him (Kennedy) than the Atlantic Community and its twin pillars". ${ }^{54}$ The Atlantic unity was a means, in other words, and struggle for the free world was basic. He had assumed Wilson's mantle. ${ }^{.5}$ 


\section{Kennedy's Speech}

The site, the time, and the audience had been carefully chosen. The annual National Governors' Conference was held in Philadelphia in 1962. And it was here he had decided to speak, on the Fourth of July (at 11.40 a.m. $)^{56}$ in Independence Hall, where the Declaration of Independence had been announced to the world in 1776 and where subsequently the US Constitution had been made in 1787. With the "states rights movement" on the rise (and no longer only in the South) ${ }^{57}$ he had resolved to give a twenty minutes' lesson in American civics. It was "symbolic politics" in the grand manner. The lesson was given in the cosmopolitan state of Pennsylvania, the state of Governor David Lawrence, one of the leading king-makers at the Democratic Convention in 1960.58 In the introductory words he emphasizes "the necessity of comity between the National Government and the several states" as a "lesson of our long history". Out of many competing interests the Governors and he as president have to weave "law and progress". They have to do it through "decision".

He then turns to that "bold decision" entitled The Declaration of Independence which still represents America as "revolutionary", as "experiment" in government, as tree enterprise, as free elections, and as independent nationhood and decolonialization. As the Nation's pontifex maximus he gives religious coloring to his language:

The theory of independence, as old as man himself, was not invented in this hall, but it was in this hall that the theory became practice, that the word went out to all, in Thomas Jefferson's phrase, that 'the God who gave us life gave us liberty at the same time.

And now with due obeisance to Lincoln:

And today this Nation, conceived in revolution, nurtured in liberty, maturing in independence - has no intention of abdicating its leadership in that world-wide movement for independence to any nation or society committed to systematic human oppression.

He then moves on to the second text in American Scripture: the US Constitution, which is seen as linking independence with interdependence, since "the liberty of one is the liberty of all". He thus manages to marry the revolutionary and the conservative documents in a manner reminiscent of a Tom Paine (whose "The Rights of Man" had been used as motto for the Democratic Platform 1960). ${ }^{59}$ 
The American spirit of weaving independence and interdependence together ("liberty" and "system" through "law", as he said earlier) is now seen as doing its work all over the world engaged in constitution-building.

It is today most clearly seen across the Atlantic ocean. The nations of Western Europe ... are joining together, seeking, as our forefathers sought, to find freedom in diversity and in unity, strength.

\section{A little later:}

We do not regard a strong and united Europe as a rival but as a partner. To aid its progress has been the basic objective of our foreign policy for seventeen years.

He pays his respect to Gen. Marshall's Harvard speech June 5, 1947 in a significant echo: ${ }^{\mathbf{6 0}}$

It would be premature at this time to do more than indicate the high regard with which we view the formation of this partnership. The first order of business is for our European friends to go forward in forming the more perfect union which will some day make this partnership possible.

And now the climax, formally as well on the substantive level:

But I will say here and now on this day of Independence, that the United States will be ready for a Declaration of Interdependence, that we will be prepared to discuss with a united Europe the ways and means of forming a concrete Atlantic partnership, a mutually beneficial partnership of the new union now emerging in Europe and the Old American Union founded here 175 years ago.

With an updated quotation from the businessman's hero in the American pantheon, Alexander Hamilton, he advises Americans today to "think intercontinentally"; the envisaged partnership must be outward-looking and thereby help to "achieve a world of law and free choice"; it must "serve as a nucleus for the eventual union of free men".

The speech is thus structured through the three tenses: the past the present - and the future. To the mythic past corresponds the myth of man's future redemption. Like Lincoln in his Gettysburg speech, which he tries to emulate in the use of the triadic time structure as well as in his allusive and inclusive use of history, he ends on "hope".61 Redemption is possible through bargaining, mutuality, reciprocity, rationality, consensus gentium, reason, dialogue, contract-building, "commerce" (:also in the old sense of the word), "comity" (:the tradition of civility). He is exhorting his countrymen to let natural law monitor and direct enactment of the 
new positive law: the TEA. ${ }^{62}$ In the conclusion he reverts to Lincoln, echoes the NATO treaty, and General Washington's Farewell Address, after which he ends with the formal pledge from the last words of the Declaration of Independence.

The speech is a rhetorical tour de force with its recycling of American history, its expression of the tribal wisdom, and its faith in the American creed as universalist. ${ }^{63} \mathrm{It}$ is an invocation of the sages of the ages, the founding fathers from the early days of the Republic down to contemporary Cold War America. They are used to endorse the new decision and the new departure. The argument from tradition is brought to bear on and coincide with the logic of the present case. Diachronically derived wisdom confirms synchronic reason, a mode of thought sometimes found in natural law and especially within the rhetoric of the Supreme Court. The orderly and reasonable progression of the speech is formally supported by antitheses and parallels, so that the argument is seen as unfolding under the reign of reason: the president is speaking the necessary consensus gentium.

Henry Fairly has commented ironically on the American inclination to think of history as starting in the year $1776 .{ }^{64}$ And in that respect Kennedy did of course perform as an orthodox American. Another Englishman, Godfrey Hodgson, was not bothered by that point, however; he praised this speech as "Kennedy's New Testament" in The Observer (July 7) and he attached importance to the fact that the old words were used in daring, new ways, as when $\mathrm{K}$ spoke of a "more perfect union with our European friends", ${ }^{65}$ which was indeed an unwarranted stretching of the actual text, at least as it had been printed. But this stretching shows something of the atmosphere and mood in which it was heard.

The speech, with all its skill, is of course cold war rhetoric. It is the merchant's and trader's rhetoric. It is a plea for a consensus that is directed, a hope and a pledge to make the world safe for (American) democracy, for a Lockean conception of "liberty". It is Harry Truman updated and academically refurbished with the aid of speech writers in possession of ready knowledge of American history. It is almost too deft.

The speech was meant as a centerpiece in the Kennedy Administration by giving rhetorical and well-rehearsed expression to the Grand Design. 


\section{The Wing-Shot Design}

De Gaulle had on May 15, 1962 said that under the American design "the federator (for Europe) would not be a European". His Foreign minister had similarly said that it would be an "Atlantic Europe, not a European Europe". ${ }^{65}$ At his famous press conference in January 1963 (after the second Cuban crisis in October and after Kennedy's Nassau meeting with MacMillan) de Gaulle decided to torpedo the American Design by denying England entrance into the EEC.

In the summer of 1963 Kennedy tried to salvage his plan with his journey to Europe. ${ }^{66}$ He spoke eloquently at the Sct. Paul-s kirche in Frankfurt on June 25, he dwelled on the German Zollverein while also invoking the German cultural heroes Goethe and Bismarck. He averred that the ongoing trade negotiations would "open up new sources of demand to give new impetus to growth and make more jobs and prosperity, for our expanding populations", including those of free nations such as Japan. ${ }^{67}$ His message was:

The future of the West lies in Atlantic partnership. ... Some say this is only a dream, but I do not agree. A generation of achievement - the Marshall Plan, NATO, the Schuman plan, and the Common Market - urges us up the path to greater unity. ${ }^{68}$

That was the summer things began to become tense. The racial issue could no longer be contained with executive action and prudent movement on the legislative front. There was intensification of the organized war on organized crime. There was exposure of scandals in the Administration. And there was the Reapportionment Revolution. ${ }^{69}$

Why was Kennedy investing so much prestige in the TEA? Presumably because it was safely old and new at the same time, and because it contained the appeal of the Atlantic mystique. But also because it was linked with his philosophy of competition. Finally and most importantly, it was seen as a multiple problem solver: it would aid the balance of payments and thus the dollar. It would discipline American business and give a green light to the growth industries, whereas retarded and retarding industries would either die out or have to get modernized. In other words: a restructuring of the economy would be enforced. But further: he would with TEA (and with his support to the Reapportionment Revolution) also try to modernize the domestic power structure. Joseph $\mathrm{Kraft}$ 
describes very plausibly how Congress has since the New Deal become a subsidy jungle, which permits formation of "negative majorities" (with unrelated, even opposed interests voting together to oppose a given bill) and in general stimulates log-rolling. ${ }^{70} \mathrm{With}$ a liberalization of the subsidy-ridden economy and thus by implication a disturbance of the log-rolling patterns in Congress, the Presidency would acquire new opportunities for assuming a stronger role as legislator for urban America. This was all the more important, since the usual conflict between "rural" and "urban" had in the USA come, over the years, to be almost institutionalized in the tug-of-war between the legislature and the executive. ${ }^{71}$ America should really be a "presidential country", to use Walter Lippmann's phrase, ${ }^{72}$ in order to realize The Pramise of American Life as outlined by Herbert Croly in 1909.73 This implied, of course, an energetic Teddy Roosevelt-like treatment of the presidential office and of Business in order to redeem the Wilsonian

The ambitions and the stakes were thus high when Kennedy invested his prestige in the TEA and delivered his Fourth of July Speech in 1962, after lengthy bi-partisan preparation and many rehearsals. It was therefore significant that Lyndon B. Johnson in his "own "Message on the State of the Union in January, 1965 informed his former Congressional colleagues that he was not bent on "abstract designs". ${ }^{75}$

\section{N O T E S}

1 Along with Arthur Schlesinger's book came Theodore Sorensen's Kennedy (New York, 1965). For the quotation, see Schlesinger, op.cit. p. 847.

2 Seymour E. Harris, op.cit., p. 173.

3 Bruce Miroff, Pragmatic Illusions (New York, 1976).

4 Cp. Bert Cochran, Harry Truman and the Crisis Presidency (New York, 1973).

5 Murray Edelman, The Symbolic Uses of Politics (Urbana, Ill., 1964).

6 Joseph Kraft, op.cit., p. 9. Other stimulating books by contemporary observers are Max Beloff, The United States and the Unity of Europe (London, 1963), and Ernest H. van der Baugel, From Marshall Aid to Atlantic Partnership (Amsterdam, London, New York, 1966). David Caleo's several, elegant books, e.g., The Atlantic Fantasy (Baltimore, London 1970,) must be mentioned as also Miriam Camps' books about EEC problems.

7 Cp. Francis K. Sutton, et al., The American Business Creed (Cambridge. Mass., 1956).

8 Harold Van B. Cleveland, The Atlantic Idea and its European Rivals (New York, 1966).

9 This rapid sketch is based on The Strategy of Peace (New York, 1960) and The President's Economic Report (Washington, 1962 and 1963), plus a great deal of 
secondary literature, e.g. Bernard Nossiter, The Mythmakers (Boston, 1964), and books by Walter Heller, Gunnar Myrdahl, John Galbraith, Michael Harrington, Erling Bjøl, N. J. Haagerup, Berge Visby, Holger Gad, and others.

10 OECD developed out of and expanded from OEEC.

11 See The Yale Commencement Address, in: Public Papers of President John F. Kennedy (Washington, 1962), p. 473.

12 Strategy of Peace, p. 199.

13 Economic Report, 1962 (Jan.).

14 James Reston, "What Was Killed Was Not Only the President. But the Promise", Neze York Times Magazine, Nov. 22, 1964, repr. in: Aida DiPace Donald, ed., John F. Kennedy and the New Frontier (New York, 1966), pp. 22-231.

15 Public Papers, 1962, p. 471.

16 Seymour Harris, op.cit., p. 41.

17 My vocabulary is colored by Walter Lippmann, particularly his The Good Society (New York, 1937), and Charles Forcey, The Cross Roads of Liberalism (New York, 1961). Ronald Steel, Walter Lippmann and the American Century (Boston, 1980) shows Lippmann's closeness to the Kennedy Administration. In Irving Babbitt, An Intellectual Portrait (Yale, 1964) I tried to describe Lippmann's closeness to the Neo-Humanism of his Harvard teacher Irving Babbitt, particularly in his later development via "natural law philosophy".

18 Cp. N. Gordon Levin, Jr., Woodrow Wilson and World Politics (Oxford, 1968) GB 1970.

19 Richard N. Kottmann, Reciprocity and the North Atlantic Triangle, 1932-1938 (Ithaca, New York, 1968).

201961 was characterized by Defense build-up, OECD, plus settling for in the Administration. 1962 by TEA, and 1963 by the Tax Reduction bill and the Civil Rights bill. As hinted in Richard E. Neustadt, Presidential Power (1960) (Signet ,1964), a president's second year should be watched especially.

21-24 Harold Porter and Donald B. Johnson, eds. National Party Platforms, 1840-1968 (Urbana, Ill., 1970), pp. 577, 578, 579, 580.

25 Harold Van B. Cleveland, op.cit., p. 120 et passim.

26 Beugel, op.cit., p. 364.

27 ib., pp. $358 \mathrm{ff}$.

28 ib., p. 370, and Alfred Grosser, The Western Alliance (English translation 1980 from French ed. 1978), New York, 1980 (Papermac ed. p. 201).

29 See Beugel and Cleveland. I shall use the abbreviations NAM for: National Association of Manufacturers and AFL/CIO for: American Federation of Labor and Congress of Industrial Organisation.

30-33 Public Papers 1962, pp. 13, 14, 49, 77. The Message accompanying the bill is even more than the earlier messages replete with anti-Communism.

34 Legislative History of H.R. 11970, 87th Congress, Trade Expansion Act of 1962 (2 vols.), Washington, D.C. 1967. As prepared by the staff of the Ways and Means Committee the vols. contain the bill, plus background materials, and hearings. (Secretary of Commerce Hodges described vividly the potential demand represented by the growing Common Market in radios, TVs, cars, refrigerators, washing machines, p. 71.)

35 Public Papers, 1962, p. 510.

36 Joseph Kraft gives an excellent summary of the bill in op.cit., p. 41.

37 Beugel, op.cit., p. 372.

38 Public Papers, 1962, pp. 759, 760.

39. Raymond Bauer, op.cit., p. 319.

40 Robert A. Dahl, Pluralist Democracy in the United States; Conflict and Consent 
(Chicago, 1967), pp. 404-416. And V. O. Key, Jr., Politics, Parties, and Pressure Croups, 5th ed. (New York, 1964).

41 Robert Dahl, op.cit., 414-15.

42 The new Southern agriculture would be waiting for an operation Breadbasket asked for in the Democratic Platform 1960.

43-44 Cp: Mary Sperling McAuliffe treatment of "Americans for Democratic Action" in her book Crisis on the Left: Cold War Politics and American Liberals, 1947-1954 (Amherst, 1978). My description of "intellectuals" is indebted to S. M. Eipset, Political Man (London, 1960), Daniel Bell's writings, and Christopher Lasch's essay on Cold War Intellectuals, In: Bernstein. ed., Towards a New Past (Vintage).

45 Henry Adams, Letters, ed. Worthington C. Ford (Boston, 138), pp. 447-448, quoted in Anwar Syed, Walter Lippmann's Philosophy § International Politics (Philadelphia, 1963), p. 210.

46 Sued, op.cit., p. 210-211.

47 Cp. Cushing Strout, The American Image $₫$ the Old World (New York, 1963).

48 Lippmann's editorial is reprinted in John A. Carraty and Robert A. Divine, ed., Twentieth Century America (Boston, 1968), pp. 161-165.

49 Kraft, op.cit.

50 Cleveland, op.cit., p. 107.

51 Cp. Coral Bell, The Debatable Alliance (London, 1964), and Churchill's History of the English Speaking Peoples (from after WWII).

52 Beugel, op.cit., 374, 369.

53 A. Grosser, op.cit., 201. My knowledge of Monnet is heavily indebted to Erling Bjøl, La France devant l'Europe (Copenhagen, 1966).

54 R. Aron, The Imperial Republic (Englewood Cliffs, N.J., 1974 transl. from French ed. Paris, 1973), p. 87.

55 N. Gordon Levin, Jr., op.cit.

56 Public Papers, 1962, pp. 537-9, from which the following quotations are taken.

57 Fred J. Cook, "The Federal Union Under Fire", The Progressive (September, 1963, pp. 10ff).

58 Theodore White, The Making $\delta$ the President (New York, 1962).

59 I owe this point about Tom Paine to Eric Foner, Tom Paine and Revolutionary America (New York, 1976).

60 H. S. Commager, ed., Documents $₫$ American History (New York, 1958), pp. $711-712$.

61 Cp. my radio talk "Abraham Lincoln og hans Ghettysburg Tale" (July, 1968), included In: Anglo-American Studies VIII (Aarhus Handelshajskole, 1969), pp. 26-33.

62 I have adopted the word "recycling" from Recycling the Past, ed. Leila Zenderland (Philadelphia, 1978).

$63 \mathrm{Cp}$. my note 17.

64 Henry Fairlie, The Kennedy Promise (New York, 1973).

65 ib., p. 113.

66 A. Grosser, op.cit., pp. 204-207. At a Press Conference (Feb. 7, 1963), asked about de Gaulle's blocking of "the admission of Britain to the Common Market" on January 14, 1963, K in his answer used the phrase: "Now, the US is prepared to make every effort to provide Europe with a strong voice ...". Public Paper, 1963, p. 149. The MacNamara doctrine of "flexible response" since May 1962 and American work for establishment of MLF ("a multilateral force") indicated attempts to fuse security politics and trade in a manner that ran counter to de Gaulle's work for (nuclear) "independence". This important dimension has for reasons of space been by-passed in the present paper; similarly de Gaulle's attempt to protect French agricul- 
ture against American farmers in regard to West Germany's workers as consumers.

67 Louis J. Hale in International Herald Tribune (June 13, 1963), wrote about European youth becoming disenchanted with J.F.K. At home there was Victor Lasky's notorious book $\mathcal{J} F K$ : The Man and the Myth (New York, 1963), on the bestseller since the spring and until November 23, when it was taken out of circulation.

68-69 Public Papers, 1963, pp. 519, 517.

70 About the Supreme Court's reform of the constituencies 1962-64 ("one man, one vote") and its upsetting effect in Washington politics during 1963, I had the opportunity to write a paper at The Salzburg Seminar in August, 1966, under expert guidance from Frank Lane, Director of Advisory Commission on Intergovernmental Relations, and from Robert McCloskey. It is included in Anglo-American Studies VIII (Aarhus Handelshajskole, 1969).

71 Kraft, op.cit., and cp. James McGregor Burns, The Deadlock of Democracy (Englewood Cliffs, N.J., 1963) about America's Four-Party System: Congressional Republicans, Presidential Republicans, Presidential Democrats, and Congressional Democrats, - with the Presidential parties working together for urban America. The thesis is repeated in Presidential Government (Boston, 1967). E. E. Schattschneider, The Semi-Sovereign People (New York, 1960), throws helpful light on this problem Rural vs. Urban Power.

72 Cp. McGregor Burns, op.cit., in note 70.

73 See Ronald Steel, op.cit., p. 525.

74 Eric F. Goldman, Rendezvous With Destiny (1965) (Vintage, 1958) was one of those historical works that came to influence history, e.g. through its description of Herbert Croly, whose The Promise of American Life 1909 was resurrected with Charles Forcey's edition of it as Dutton pb. 1963.

75 Cp. John M. Blum, The Republican Roosevelt (1954), similarly a historymaking historical work, published as Atheneum pb 1962. And cp. Charles Forcey, The Crossroads of Liberalism (Croly, Weyl, Lippmann) New York, 1961. These books were of course written before William Appleman Williams and his descendants tore the veil aside.

76 Ernest Preeg, a member of the US negotiating team in the Kennedy Round has given a lucid and sympathetic description of the course of the negotiations, which after many unforeseen difficulties were brought to a reasonably successful end in October, 1967 (when the presidential negotiating authority expired). See his Traders and Diplomats (Washington, 1970). In industrial products the average tariff reduction amounted to $35 \%$, agricultural products were barely touched. It became abundantly clear that there are many other trade barriers than just tariffs. 


\section{Authors in this Issue}

IngA Floto, b. 1937, Dr.phil. from the University of Copenhagen 1973, is associate professor at the Institute for Contemporary History, University of Copenhagen, and co-editor of Historisk Tidsskrift (Danish Historical Review). Her field of research and teaching includes 20th century American history and historiography. Major publications: Colonel House in Paris. A Study of American Policy at the Paris Peace Conference 1919 (Aarhus 1973 and Princeton, 1980) and Woodrow Wilson and the European Left at the Woodrow Wilson Symposium, Princeton Oct. 1979. (To be published 1981).

Niels Thorsen, b. 1947 is associate professorat the Department of English, University of Copenhagen. He received his Ph.D. in history and American political theory at Princeton University, 1980. His works include the dissertation: The Political and Economic Thought of Woodrow Wilson 1875-1902, articles in Historisk Tidsskrift, and text-books on American history.

Erik Helmer Pedersen, b. 1934, is associate professor at the Institute for Economic History, University of Copenhagen, where he received his Dr. phil.degree in 1979. Recent results of his work in Danish immigration history and American agricultural history are: Brev fra Danmark (Letter from Denmark), (Copenhagen, 1981) and "Danish Farms in the United States", The Bridge, 6, 1981.

Mette Skakkebæk, b. 1943, cand.phil. 1977 Copenhagen is research fellow at the Institute for Contemporary History, University of Copenhagen. The article in this issue is part of a research project on the social and economic background for the Socialist Party in Illinois, 1900-32. Other publications are "Agrarian Radicalism after the Populists". American Studies in Scandinavia vol. 11, 1979. and articles in Danish Historisk Tidsskrift on American labor history.

LENE Koch, b. 1947 is cand.mag. from the University of Copenhagen, 1978. She is lecturer at the Department of English, University of Copenhagen, where she teaches American labor and women's history. In addition to various articles on American society, she is co-author of an article on civil rights legislation in the USA in the legal journal Retferd, nr. 11, 1980.

Erik Arne Hansen, b. 1924, Ph.D. in history from Yale 1964, is associate professor of English and American Studies at the English Institute, University of Aarhus, where he teaches American cultural and constitutional history. His publications include: "From New Deal to New Frontiers", in Six: American Novels, eds. : Bøgh and Skovmand (Copenhagen 1972) and Danish textbooks on American 20th century society. The article in this volume is part of his work on a textbook on the Kennedy administration and a series of essays on political rhetoric called "The American Creed in Formation and Disease". 